
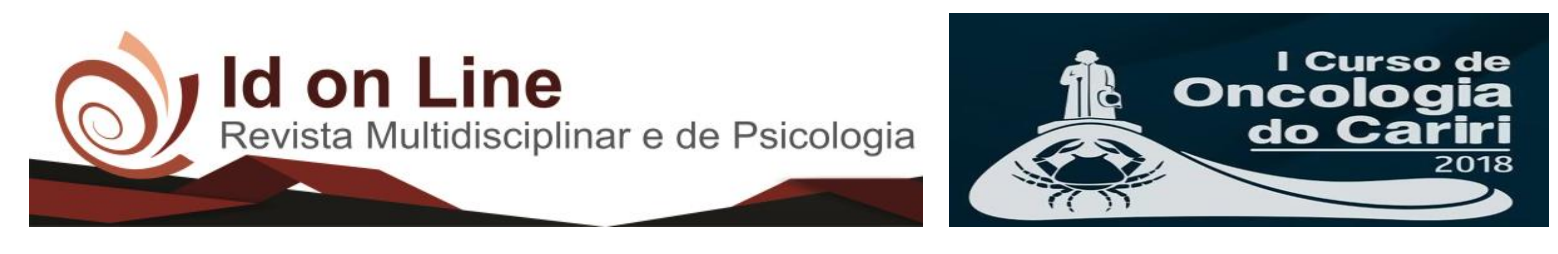

Resumo

\title{
A IMPORTÂNCIA DO JAK-2 NA CONDUTA TERAPÊUTICA DOS CÂNCERES HEMATOLÓGICOS
}

\author{
Raquel Lemos Bessa de Oliveira ${ }^{1}$; Helen Fernanda de Oliveira Sousa, \\ Mirella Náiade Gomes Pereira'; Itamar Alves Araújo ${ }^{1}$.
}

Introdução: Os cânceres hematológicos são doenças de natureza clonal que acometem qualquer faixa etária e sexo, tendo como característica comum uma proliferação celular exacerbada devido a desregulação da via de sinalização de tirosina-quinase, principalmente, a família Janus kinase (JAK) em especial a JAK-2. Objetivo: Apresentar uma análise da importância da presença de mutação no gene JAK-2 como fator etiológico comum dessas neoplasias. Método: Utilizou-se no presente trabalho uma revisão de literatura em que foram analisados artigos científicos pesquisados nas bases de dados PUBMED, Scielo, SciHub e Google acadêmico, usando como descritor, principalmente, a importância do JAK-2 na conduta terapêutica dos cânceres hematológicos. Todos os artigos pesquisados estão em língua inglesa e portuguesa. Resultados: A proteína JAK-2 está envolvida no processo de sinalização de receptores de citocinas como IL-3, IL-5, IL-13, hormônios do crescimento, eritropoietina e trombopoietina, assim, quando ligada aos receptores, ativa o processo de transdução gênica. Entretanto, algo que iniba ou desajuste essa via pode contribuir para o desenvolvimento de neoplasias hematológicas. Conclusão: Dessa forma, é de suma importância estudos de investigações de mutações nesse gene, assim como análise do perfil imunofenotípico das células leucêmicas e sua associação com as manifestações clínicas para a elaboração precoce do diagnóstico de neoplasias hematológicas, contribuindo desse modo para um melhor entendimento e viabilização de descobertas sobre novas drogas e tratamentos variados.

Palavras-chave: mutação do gene JAK-2; diagnóstico precoce; novas terapias.

\footnotetext{
${ }^{1}$ Discentes da Faculdade de Medicina Estácio de Juazeiro do Norte; Autor correspondente: raquellemos27@gmail.com.
}

43 Id on Line Rev. Mult. Psic. V.12, N. 40. 2018 - ISSN 1981-1179 EDIÇÃO ESPECIAL: I CURSO DE ONCOLOGIA DO CARIRI / II JORNADA DE PESQUISA QUANTI-QUALITATIVA EM ONCOLOGIA. JUAZEIRO DO NORTE, 05 A 10 DE MARÇO DE 2018. Edição eletrônica em http://idonline.emnuvens.com.br/id 